\title{
Market Transition Theory Revisited: Changing Regimes of Housing Inequality in China, 1988-2002
}

\author{
Xi Song, ${ }^{a}$ Yu Xie ${ }^{b}$ \\ a) University of California Los Angeles; b) University of Michigan and Peking University
}

\begin{abstract}
This paper revisits the market transition theory of Nee (1989), using housing as an alternative to income as a measure of socioeconomic attainment. We argue that housing space is a better outcome variable by which to evaluate Nee's market transition theory because it is a more consistent measure of socioeconomic success than income before and after the economic reform. Using three waves of a national household survey in 1988, 1995, and 2002, we compare temporal changes in the role of market and redistributive determinants for income and housing space. In support of a weak form of the theory, our results show that market determinants replaced redistributive determinants over time as the most significant predictors of housing space. In contrast, parallel analyses of income show mixed results for market and redistributive determinants.
\end{abstract}

Keywords: China; economic reform; market transition theory; housing inequality

Editor(s): Jesper Sørensen, Kim Weeden; Received: May 7, 2014; Accepted: June 3, 2014; Published: July 21, 2014

Citation: Song, Xi and Yu Xie 2014. “Market Transition Theory Revisited: Changing Regimes of Housing Inequality in China, 1988-2002." Sociological Science 1: 277-291. D0I: 10.15195/v1.a18

Copyright: (C) 2014 Song and Xie. This open-access article has been published and distributed under a Creative Commons Attribution License, which allows unrestricted use, distribution and reproduction, in any form, as long as the original author and source have been credited.

$\mathrm{N}$ EE'S (1989) market transition theory conjectures that China's economic reform is a process in which markets replace political authority in the distribution of resources and predicts that human capital factors gradually replace political factors as determinants of socioeconomic success. While income returns to education have indeed increased in China over time, it remains unclear whether this trend should be interpreted as supporting Nee's market transition theory (Hauser and Xie 2005). Most notably, researchers have found overwhelming evidence of the persistence of political power in determining income (Bian and Logan 1996; Walder 1990, 1995, 2002; Walder and Zhao 2006; Wu 2002; Zhou 2000).

Past debates on market transition theory between Nee and his critics have relied almost exclusively on income as a preferred measure of socioeconomic attainment. The narrowness of this criterion may account for the inconclusiveness of empirical results in previous research. In this paper, we argue that income may be an inadequate outcome variable for the evaluation of market transition theory, since its distribution was largely egalitarian under the redistributive regime and thus income did not accurately reflect social status before the reform. Hence, we raise the following question: Can the empirical inconsistency in previous research in testing market transition theory be attributed to the inadequacy of income as a measure of stratification outcome?

One way to answer this question is to use an alternative outcome variable that more consistently measures socioeconomic attainment both before and after the reform. In this paper, we propose housing as such an alternative variable for revisiting and reevaluating Nee's market transition theory. Using three repeated, cross-sectional, nationally representative surveys, we analyze the changing determinants of socioeconomic attainment at various stages of the reform, from the late 1980 s to the early 2000s. The empirical evidence on housing is consistent overall with the predictions of the market transition theory, whereas parallel analyses of income show mixed results for market and redistributive determinants. 
Market Transition and Housing Inequality

\section{Market Transition Theory}

Nee's (1989) market transition theory maintains that China's economic reform shifts the primary mechanism of distributing resources from a political, redistributive system to a market-oriented system. As a result, this foundational shift benefits "direct producers" who actively engage in market activities and undermines the privileges of former "political redistributors." The Chinese economic reform, therefore, reshapes the social stratification system by "changing the determinants of the socioeconomic attainment" (Nee 1989, p.663). More concretely, market transition theory asserts that the economic reform would lead to a decline of political capital and the increasing importance of human capital in determining socioeconomic outcomes (Nee 1989).

Market transition theory has stimulated a lively, still ongoing debate about the social consequences of economic transformation in former communist societies (e.g., Bian and Logan 1996; Cao and Nee 2000; Gerber and Hout 1998; Hauser and Xie 2005; Nee 1991, 1996; Nee and Cao 2005; Nee and Matthews 1996; Parish and Michelson 1996; Szelényi and Kostello 1996; Walder 1995, 1996, 2002; Walder and Nguyen 2008; Walder and Zhao 2006; Wu and Xie 2003; Xie and Hannum 1996; Zhou 2000). Central to the debate is the validity of the theory, and scholars have tested market transition theory by using empirical evidence from various periods and geographic regions. Research findings in this area, however, have thus far been inconclusive.

Two empirical findings appear consistent with market transition theory. First, income returns to education have significantly increased over time (e.g., Hauser and Xie 2005). Second, income returns to education are higher in the private sector than in the state sector (e.g., Zhao and Zhou 2002). These findings, however, may be subject to explanations other than market transition theory. For the increase in income returns to education, Hauser and Xie (2005) argued that economic development itself, rather than marketization, may be responsible, with China's development leading to higher levels of economic inequality and higher income returns to education. This argu- ment is rooted in the economic reasoning that "individuals who are more efficient resource allocators will be better able to take advantage of the changed opportunity sets" (Chiswick 1971, 28). Wu and Xie (2003) attributed the sectorial differences in income returns to selective sorting, the private sector being highly heterogeneous and consisting of workers who transitioned from the state sector either because they were attracted by higher economic payoffs in the private sector (xiahai) or because the government had laid them off (xiagang).

Researchers have also uncovered strong evidence to refute the market transition theory. Capitalizing on the huge regional unevenness in economic development that resulted from the unequal progress of the economic reform in China, Xie and Hannum (1996) found that income returns to education are higher in slow-developing cities than in fast-developing cities, with the pace of economic development measuring that of the economic reform. Walder (1990) and Wu (2002) also reported that returns to education were lower for bonuses set by work units (danwei) than for base salaries set by the government. Most importantly, overwhelming evidence from previous research has shown that political power continues to play a major role in determining economic income in a variety of social contexts, especially when ownership of enterprises is ambiguous and the governments' role is strong (Walder 2002; Walder and Zhao 2006).

Most theoretical and empirical studies have used income or earnings as the outcome variable when evaluating market transition theory. Income, however, is problematic for this test, especially in a trend analysis, because it was distributed on the basis of egalitarian or formulaic principles and thus did not reflect the true dimension of social inequality in pre-reform or early reform China. For example, in the late 1970s, the Gini coefficient for income inequality was reported to be only between 0.16 and 0.19 (Adelman and Sunding 1987; Hauser and Xie 2005). Not until the economic reform did income emerge as a meaningful measure of socioeconomic attainment. The economic reform led to rapid growth not only in average income but also in the variation of income distribution. The Gini coefficient increased to higher than 0.3 in the 1990s and continuously and rapidly to the $0.53-0.55$ range 
around 2010 (Xie and Zhou 2014). The significant increase in the variation of income suggests not only that income determinants have changed, as market transition theory predicts, but that the social significance of income has changed as well 1

The problematic nature of income as a stratification outcome was recognized by Walder early on. In two studies based on a 1986 survey in Tianjin, Walder $(1992,1995)$ explicitly discusses the limitations of income, stating that "income does not reflect standards of living in centrally planned economies to the same degree as in market economies" (Walder 1995, 322). This is because socialist regimes rewarded top-tier workers in the political hierarchy not with cash income, but with concrete goods and services, the most valuable of which was a set of public housing units (Szelényi 1978, 1983; Walder 1986, 1992). Walder's (1995) solution was to focus on housing space as a more meaningful measure of social stratification. As Walder (1995, p.322) argued, "In China housing is a particularly accurate indicator of privilege, because housing space is extremely scarce in urban areas."

Housing space is a good measure of social stratification both before and after the economic reform. As we will discuss below, the economic reform has largely preserved the unequal distribution of housing in China, but it has dramatically switched the social groups that have better access to housing. At the same time, competition for housing has only intensified, in part because housing ownership has become a major way to generate private wealth (Meng 2007). Recall that market transition theory predicts changes in the determinants of "socioeconomic attainment" without specifying what constitutes socioeconomic attainment. A fair evaluation of the theory thus needs a socioeconomic attainment measure whose significance of social stratification has remained consistent over time. For this purpose, we argue that housing space serves as a better outcome measure than income in assessing market transition theory.

\footnotetext{
${ }^{1}$ Let us demonstrate this further with a statistical property of regression. Assume that the correlation between an outcome $Y$ and an independent variable $X$ is unchanged, and so is the variance of $X$. An increase in the variance of $Y$ means that the regression coefficient of $X$ on $Y$ would necessarily increase.
}

\section{Housing Reform}

Admittedly, we are not the first to acknowledge the importance of housing in social stratification studies of post-reform China. Sociologists have been interested in housing inequality in China from the beginning of the economic reform. Initially, this was because they hoped to use housing space as an additional, perhaps more reliable measure of socioeconomic status (Logan and Bian 1993; Parish 1984; Whyte and Parish 1984; Walder 1995). More recently, interest has focused on the housing reform and its social consequences (Chen and Gao 1993; Huang and Clark 2002; Sato 2006; Wang 1995; Wang 2003, 2008; Wu 1996). As far as we know, most studies thus far have examined housing inequality at a single point in time, while very few have assessed the changing determinants of housing throughout the reform.

In pre-reform urban China, work units, or dan$w e i$, provided housing as a form of fringe benefit, the quality of which largely depended upon a danwei's administrative rank assigned by the central government as well as a worker's administrative rank within the danwei (Bian et al. 1997; Chao 1966; Howe 1968; Lee 1988; Yang and Zhou 1999; Zhou and Logan 1996). For example, cadres, especially those who worked for the local government, had better access to larger and higher quality housing than ordinary workers from stateor privately owned enterprises. To improve economic efficiency and to encourage labor mobility, the Chinese government implemented housing reform by privatizing public housing units and promoting the development of real estate markets (Zang 1999). Although Chinese leaders were discussing housing reform as early as 1978, not until 1980 were housing commercialization plans formalized in the National Urban Housing and Residence Meeting. In 1988, the State Council's National Housing Reform Meeting approved employees buying existing public housing stock from their danwei. Finally, a 1998 directive of the State Council ordered all state-owned danwei to stop building any new public housing units for employees, and instead began subsidizing workers who wished to purchase existing public housing units from their danwei, as well as encouraging workers to purchase new private housing units from the market directly (Pan 2000). This last measure completed the government's official ef- 
fort in housing reform and triggered rapid growth of the real estate industry in urban China. The market sector accounted for an increasing share of the total annual housing supply: from 13 percent in 1986 to 33 percent in 1993, and to 72 percent by 2006 (Wu, Gyourko, and Deng 2012).

\section{Changes in Housing Inequality}

It is well known that personal income in China has increased rapidly and steadily since the beginning of the economic reform in 1978. For example, per capita household income in urban China grew from 316.0 in 1978 to 3,892.9 yuan in 1995 (National Bureau of Statistics 1996). Parallel to this overall increase in family income, but less widely known, is the fact that the housing conditions of Chinese urban families have also improved tremendously during the same period. Using housing space, which is comparable temporally and regionally, as a measure, we find that the average per-person housing space in urban China grew from 3.6 square meters in 1978 to 9.3 square meters in 1998 (National Bureau of Statistics 2003).

One remarkable difference between housing and income is that housing has remained not only a valuable possession that almost all Chinese families desire but also a consistent marker of socioeconomic status (Logan, Fang, and Zhang 2009, 2010; Walder and He 2014). Before the economic reform, housing was in severe shortage, and the administrative class used its power to allocate housing benefits as one of the main rewards for cooperative workers in a paternalistic relationship (Walder 1986). Since the economic reform, housing has remained in high demand (Walder 1995), as indicated by the huge housing price increases in major Chinese cities ${ }^{2}$ (National Bureau of Statistics 2003). Housing now constitutes a major avenue through which most urban Chinese families accumulate wealth (Meng 2007; Yemtsov 2007), because housing reform policies privileged all urban residents by allowing them to purchase housing units at deeply subsidized prices (Logan, Fang, and Zhang 2009, 2010; Walder and He 2014).

\footnotetext{
${ }^{2}$ The China Statistical Yearbook only recorded the average selling price of commercial housing in major cities after 1997.
}

In Chinese cities, the most common form of housing is an apartment in a multi-unit building. Although the monetary value of such a unit depends on many factors, such as location, amenities, and services, as in other countries, we concur with Walder (1995) that housing space is an excellent indicator of socioeconomic outcome that can be measured accurately and consistently regardless of time and location. Even prior to the economic reform, housing space was regarded as a leading determinant of social inequality, or even the single most important indicator of one's position in the social hierarchy (Bian 2002; Szelényi 1978, 1983; Zhou and Logan 1996). For example, the official standard for housing size varied from 42 square meters for families of ordinary workers to more than 90 square meters for families of high level cadres (Logan, Bian and Bian 1999).

The housing reform initially preserved the old form of inequality by allowing danwei to sell existing housing units to their residents at subsidized prices. Yet the housing reform also gave rise to a new form of inequality, as urban Chinese who were unsatisfied with their living accommodations could purchase apartments at market prices on the emerging housing market. Almost all housing developers and government statistical agencies quote housing prices in terms of price per square meter (Wu, Gyourko, and Deng 2012). Given this widespread practice, the total amount of square meter space directly reflects the total value of the home - thus it reflects the accumulation of wealth in the form of housing ownership.

As will be discussed later in the paper, the variance of housing space, a measure of inequality, remained largely the same during the reform period in urban China. However, we have reason to believe that the social determinants of housing have changed significantly. Before the economic reform, administrators who were closely connected with distributing government resources enjoyed an advantage in housing space. After the reform, the central government and danwei withdrew themselves from direct involvement in housing allocation and instead encouraged employees to purchase homes themselves from the emerging housing market. This transition means that political factors should gradually become less important in determining housing space, while economic factors should become more important. 


\section{Research Question}

In this paper, we examine trends in the determinants of housing space in urban China, contrasting them with those of personal income. We expect the trends for housing to be consistent with those predicted by market transition theory for two reasons. First, housing space is an important marker of socioeconomic success that is consistent over time. Second, housing in urban China has undergone a complete reform, transitioning from administrative to market allocation. For these two reasons, we argue that housing is a much better measure of socioeconomic attainment than personal income for empirical evaluations of market transition theory.

\section{Data, Measures and Methods}

We analyze data from the 1988, 1995, and 2002 urban surveys of the "Chinese Household Income Projects" (henceforth, CHIP88, CHIP99 and CHIP2002). The 1988 wave interviewed 9,009 households from 64 cities in ten provinces (Beijing, Shanxi, Liaoning, Jiangsu, Anhui, Henan, Hubei, Guangdong, Yunan, and Gansu). Based on the same sampling framework but with the Sichuan province included, the project interviewed 6,931 households from 69 cities in 1995 and 6,835 households from 62 cities in 2002 . The provinces covered by the CHIP surveys are diverse in terms of geographical location, size, population, and level of economic development. The complete dataset and documentation are publicly available for download at the Interuniversity Consortium for Political and Social Research ${ }^{3}$ Several early published studies have relied on the data for analyzing the market transition in China (Hauser and Xie 2005; Pan 2003).

An advantage of using these datasets is that they cover the critical period of the housing reform. As noted earlier, the housing reform did not begin until 1988, when the National Housing Reform Meeting approved a scheme encouraging danwei to privatize public housing units. We use the CHIP data of 1988 as a baseline at the very beginning of the housing reform. Our most recent data were collected in 2002, four years after the

${ }^{3}$ See http://www.icpsr.umich.edu/icpsrweb/ICPSR/ series/243 for CHIP data and documentation. enactment of the 1998 directive for full privatization of housing. Thus, the trend we observe between 1988 and 2002, with a middle snapshot in 1995, provides an excellent window through which to view the changing roles of redistributive versus market housing determinants. Moreover, since the CHIP surveys collected rich information on all household members, we have both individual information from employed household heads and aggregated demographic information on the whole household.

The dependent variables include a household's living space and the household head's income. We choose housing size instead of housing value for several reasons. First, because housing units were all publicly owned before the reform, the estimation of housing value was not possible in 1988. Second, due to huge regional differences in housing prices, housing value would be a poor indicator of economic wellbeing across cities. Third, families may have difficulty accurately estimating the market value of their homes if they do not consider trading them on the market (Gustafsson, Li, and Wei 2006; Li and Zhao 2007). In contrast, most families have no difficulty reporting the total size of their dwelling unit. Given these considerations, we choose housing space as the dependent variable with which to measure housing inequality $4^{4}$

The key explanatory variables of theoretical interest include measures of redistributive determinants and market determinants. Other control variables include age of household head and household size, which is the number of household members currently living in the dwelling unit. We explain the two sets of our key independent variables in detail below.

Measures of market determinants include logged household annual incom $\$^{5}$ and years of schooling. To capture a household's labor income, we calculated annual income as the sum of the salaries of all the sampled family members in the previous year. Although subsidies consti-

\footnotetext{
${ }^{4}$ We tried to differentiate households who own their homes from those who rent them. However, except in large cities with many migrants, the rate of ownership is very high in China. The results in the temporal analyses are not affected by this restriction by ownership.

${ }^{5}$ The CHIP datasets asked detailed questions on various aspects of people's incomes, including base salaries, bonuses, subsidies, etc. The calculation methods toward the household income are available upon request.
} 
Table 1: Descriptive Statistics by Year

\begin{tabular}{lccc}
\hline & 1988 & 1995 & 2002 \\
\hline Individual Level (Head of Household) & & & \\
Individual annual income (yuan) & 1669.4 & 6436.6 & 12678.2 \\
& $(1200.3)$ & $(3387.9)$ & $(8570.2)$ \\
Cadre status (\%) & 12.2 & 15.6 & 14.0 \\
Years of schooling & 10.8 & 12.0 & 12.4 \\
& $(3.2)$ & $(2.9)$ & $(2.8)$ \\
Type of danwei (\%) & & & \\
$\quad$ Government and public institutions & 12.5 & 33.3 & 34.1 \\
$\quad$ State-owned enterprises & 86.1 & 65.3 & 42.7 \\
Private enterprises & 1.4 & 1.5 & 23.2 \\
Age & 41.7 & 41.8 & 43.4 \\
& $(9.4)$ & $(8.4)$ & $(7.9)$ \\
Household Level & & & \\
Housing space (square meters) & 41.2 & 46.4 & 54.6 \\
Household income (yuan) & $(22.9)$ & $(24.7)$ & $(27.7)$ \\
& 3162.9 & 11780.5 & 23375.2 \\
Family size & $(2066.1)$ & $(6535.7)$ & $(14976.3)$ \\
& 3.4 & 3.2 & 3.0 \\
Observations & $(1.0)$ & $(0.7)$ & $(0.7)$ \\
\hline
\end{tabular}

Note: Figures in parentheses are standard deviations. Source: 1988, 1995, 2002 China Household Income Project (CHIP).

tute a significant share of total income after the economic reform (Xie and Hannum 1996), we excluded them from our calculation of total household income to ensure a consistent cross-year comparison. All three surveys asked individuals about their average monthly income (including salary and bonuses). We constructed annual income by multiplying monthly income by 12 . We leave the income measure unadjusted for inflation over time. Following past studies on the market transition debate, we consider education a market determinant and extrapolate years of schooling from levels of educational attainment (illiterate/less than three years of schooling $=0$; three years of schooling but less than primary school $=3$; primary school $=6$; lower middle school $=9$; upper middle school $=12$; trade school $=13$; community $/$ technical college $=14$; college $=15$; university $=16$; and graduate school=19).

Measures of redistributive determinants include an individual's type of danwei and cadre status. We differentiate between three danwei types: government/public sector, state-owned/ collectively owned enterprises, and private enterprises, the first type possessing a political advantage and the last a political disadvantage under the pre-reform regime. We operationalize cadres as administrators or heads in government and state-owned enterprises, and professionals who work in the public sectors and receive professional titles authorized by a provincial or municipal personnel bureau $\sqrt[6]{6}$ The reference group of this dummy variable is the group of ordinary workers in the government and state-owned sectors and all the workers in the private sector.

We present basic descriptive statistics of the variables by survey year in Table 1 . From 1988 to 2002 , the average housing space increased from 41.2 square meters to 54.6 square meters. Meanwhile, the average annual household income sky-

\footnotetext{
${ }^{6}$ In fact, we also tried to define only the administrators in public sectors as the group with political privileges, but there were too few such cases in the CHIP data, and some small cities were dropped from the final sample being analyzed.
} 
rocketed from 3,163 yuan to 23,375 yuan 7 The descriptive analysis also reveals that the average educational level increased from 10.8 years to 12.4 years. The proportion of household heads working in government and public institutions increased from 12.5 percent to 34.1 percent. Accordingly, the percentage of household heads working in state-owned enterprises went down dramatically from 86.1 percent to 42.7 percent 8 The proportion of heads who were cadres went from 12.2 percent in 1988 to 15.6 percent in 1995 before declining slightly to 14.0 percent in 2002 .

Our statistical analyses of the three waves of data proceed in two steps. First, we estimate a model of housing determination at each period while ignoring regional variation and compare the results across the years 1988, 1995, and 2002. We compare the results with those from a parallel analysis for personal income. We are concerned that the results from the simple trend analysis assuming regional homogeneity may be spurious due to very large regional variation. Hence, our next step is to control for regional variation by using fixed effects at the city level and consider whether the results from both the income and the housing analyses assuming regional homogeneity still hold true.

\section{Results}

The first three columns of Table 2 present estimates of income determinants for 1988, 1995 and 2002. The models are additive ordinary least square regressions with logged income as the dependent variable and three sets of explanatory variables: market determinants, redistributive determinants, and demographic determinants. The last three columns provide statistical tests for significance of the difference in a coefficient between two years. The results confirm earlier findings of Bian and Logan (1996) and Zhou (2000) that suggest coevolution of redistributive and market determinants; that is, cadre status, danwei, and education all significantly influenced a worker's

\footnotetext{
${ }^{7}$ These are the original numbers reported in the data. We also tried to adjust for inflation with reference to the year 1988. The results are similar to those reported in the paper.

${ }^{8}$ These descriptive statistics refer to the heads of households and thus are not representative of the urban labor force as a whole.
}

income at various times in the reform era. Consistent with the market transition theory, the results show that education was increasingly explanatory of individuals' incomes, as the net return to schooling almost quadrupled from 1988 to 2002 (the coefficient increases from 0.013 to 0.054 ).

The role of work sectors and cadre status persisted rather than disappeared, however, which contradicts the prediction of market transition theory. Relative to ordinary workers, the income advantage of cadres slightly increased from 1988 to 2002, although the change is not statistically significant. Compared to workers in state-owned enterprises, government employees gained more income advantages over the course of the reform, whereas workers in the private sector lost their advantages during the period, ceteris paribus. We speculate that the emerging income premium of workers in state-owned enterprises after 1995 could be attributed to the reform of state-owned enterprises in the late 1990s, which was aimed at closing or privatizing state firms that experienced severe financial hardship and increasing wages of workers in state-owned sectors (Xia et al. 2013). For the demographic covariates, the results show that both age and family size became weaker explanatory factors for workers' income during the period under examination.

We conduct parallel analyses for housing in Table 3 using logged housing space as the dependent variable. The changing patterns of the market and redistributive determinants over time suggest a clear trend that is consistent with the predictions of market transition theory. Specifically, the effects of the market determinants education and household income on housing space increased from 1988 to 2002 . In 1988, a year's extra schooling was associated with only a 0.6 percent increase in housing space in 1988, with a 0.1 percent increase in 1995 , and a 1.7 percent increase in 2002. Thus, the role of education grew most significantly from 1995 to 2002 . Likewise, each percent increase in household income resulted in a 0.036 percent increase in housing space in 1988, a 0.061 percent increase in 1995, and a 0.085 percent increase in 2002 . For example, if a worker's income were doubled (100 percent increase) in 2002, it would lead to roughly a nine percent increase in his housing space. Overall, the results suggest that the effect of household income on housing space increased steadily from 
Table 2: Changing Determinants of Income without Regional Variations

\begin{tabular}{lcccccc}
\hline Individual income & & & & 1995 & 2002 & 2002 \\
\hline Market Determinant & 1988 & 1995 & 2002 & vs. 1988 & vs. 1995 & vs.1988 \\
$\quad$ Years of schooling & $0.013^{\dagger}$ & $0.032^{\dagger}$ & $0.054^{\dagger}$ & $0.018^{\dagger}$ & $0.022^{\dagger}$ & $0.041^{\dagger}$ \\
& $(0.001)$ & $(0.003)$ & $(0.003)$ & $(0.003)$ & $(0.004)$ & $(0.003)$ \\
Redistributive Determinants & & & & & & \\
$\quad$ Type of danwei (SOE omitted) & & & & & & \\
$\quad$ Government & $-0.125^{\dagger}$ & $0.058^{\dagger}$ & $0.090^{\dagger}$ & $0.183^{\dagger}$ & 0.032 & $0.214^{\dagger}$ \\
$\quad(0.013)$ & $(0.015)$ & $(0.020)$ & $(0.021)$ & $(0.022)$ & $(0.023)$ \\
$\quad$ Private enterprises & $0.150^{*}$ & $0.168^{*}$ & $-0.090^{\dagger}$ & 0.019 & $-0.258^{\dagger}$ & $-0.240^{\dagger}$ \\
& $(0.060)$ & $(0.070)$ & $(0.020)$ & $(0.098)$ & $(0.068)$ & $(0.074)$ \\
Cadre & $0.089^{\dagger}$ & $0.070^{\dagger}$ & $0.106^{\dagger}$ & -0.019 & 0.036 & 0.017 \\
& $(0.014)$ & $(0.019)$ & $(0.024)$ & $(0.024)$ & $(0.027)$ & $(0.026)$ \\
Demographic Determinants & & & & & & \\
$\quad$ Age & $0.013^{\dagger}$ & $0.016^{\dagger}$ & $0.008^{\dagger}$ & $0.002^{*}$ & $-0.008^{\dagger}$ & $-0.006^{\dagger}$ \\
& $(0.000)$ & $(0.001)$ & $(0.001)$ & $(0.001)$ & $(0.001)$ & $(0.001)$ \\
Family size & $0.023^{\dagger}$ & -0.012 & -0.002 & $-0.034^{\dagger}$ & 0.010 & $-0.025^{*}$ \\
& $(0.004)$ & $(0.010)$ & $(0.012)$ & $(0.010)$ & $(0.014)$ & $(0.011)$ \\
Intercept & $6.560^{\dagger}$ & $7.621^{\dagger}$ & $8.268^{\dagger}$ & & & \\
& $(0.027)$ & $(0.055)$ & $(0.081)$ & & & \\
Observations & & & & & & \\
$\mathrm{R}^{2}$ & 7,872 & 5,143 & 4,661 & & & \\
\hline
\end{tabular}

Note: Years of education, type of danwei, cadre status, and age are all measured for the head of the household. Standard errors in parentheses. Source: 1988, 1995, 2002 China Household Income Project (CHIP).

${ }^{*} p<0.05, \dagger p<0.01$ (two-tailed tests).

1988 to 1995 and from 1995 to 2002 , with the magnitude of the effect more than doubling during the 14-year period.

With the importance of market determinants on the rise, the roles of redistributive determinants declined sharply. The housing space of a cadre's family was 15.3 percent more than that of an ordinary worker's family in 1988, but the advantage declined to 13.7 percent in 1995 and 8.4 percent in 2002 . The average size of a housing unit for a government employee's family was 17.5 percent larger than that for the family of a worker in a state-owned enterprise in 1988, 12.4 percent larger in 1995, and 10.7 larger percent in 2002, ceteris paribus. The differences between workers in state-owned enterprises and privately owned enterprises were not statistically significant in 1988, owing to the large variance of housing space among workers in private enterprises. The results suggest that government employees, especially cadres, lost their relative housing advantages over time.

Let us now turn to the demographic determinants. Age, which used to be an important factor in housing allocation during the redistributive period, became a less pronounced determinant of housing space after the reform. Family size, however, still played a decisive role in housing space, with an additional person associated with a roughly nine percent increase in the housing size both in 1988 and 2002. This is easy to interpret. Before the reform, family size was an important factor that danwei took into consideration in allocating housing units among workers. 
Table 3: Changing Determinants of Housing Space without Regional Variations

\begin{tabular}{lcccccc}
\hline & & & & 1995 & 2002 & 2002 \\
Housing space (logged) & 1988 & 1995 & 2002 & vs. 1988 & vs. 1995 & vs.1988 \\
\hline Market Determinants & & & & & & \\
Household income (log yuan) & $0.036^{\dagger}$ & $0.061^{\dagger}$ & $0.085^{\dagger}$ & 0.024 & 0.024 & $0.048^{\dagger}$ \\
& $(0.012)$ & $(0.012)$ & $(0.012)$ & $(0.017)$ & $(0.017)$ & $(0.017)$ \\
Years of schooling & $0.006^{\dagger}$ & 0.001 & $0.017^{\dagger}$ & -0.005 & $0.017^{\dagger}$ & $0.011^{\dagger}$ \\
& $(0.002)$ & $(0.002)$ & $(0.003)$ & $(0.003)$ & $(0.004)$ & $(0.003)$ \\
Redistributive Determinants & & & & & & \\
$\quad$ Type of danwei (SOE omitted) & & & & & & \\
$\quad$ Government & $0.175^{\dagger}$ & $0.124^{\dagger}$ & $0.107^{\dagger}$ & $-0.051^{*}$ & -0.018 & $-0.069^{\dagger}$ \\
& $(0.016)$ & $(0.015)$ & $(0.016)$ & $(0.022)$ & $(0.022)$ & $(0.023)$ \\
Private enterprises & 0.086 & 0.070 & $0.050^{\dagger}$ & -0.016 & -0.020 & -0.036 \\
& $(0.046)$ & $(0.054)$ & $(0.016)$ & $(0.069)$ & $(0.055)$ & $(0.047)$ \\
Cadre & $0.153^{\dagger}$ & $0.137^{\dagger}$ & $0.084^{\dagger}$ & -0.016 & -0.053 & $-0.068^{\dagger}$ \\
& $(0.017)$ & $(0.018)$ & $(0.020)$ & $(0.025)$ & $(0.027)$ & $(0.026)$ \\
Demographic Determinants & & & & & & \\
Age & $0.011^{\dagger}$ & $0.008^{*}$ & $0.002^{*}$ & $-0.003^{\dagger}$ & $-0.006^{\dagger}$ & $-0.009^{\dagger}$ \\
Family size & $(0.001)$ & $(0.001)$ & $(0.001)$ & $(0.001)$ & $(0.001)$ & $(0.001)$ \\
& $0.085^{\dagger}$ & $0.105^{\dagger}$ & $0.088^{\dagger}$ & 0.020 & -0.017 & 0.003 \\
Intercept & $(0.006)$ & $(0.009)$ & $(0.010)$ & $(0.011)$ & $(0.014)$ & $(0.012)$ \\
& $2.451^{\dagger}$ & $2.436^{\dagger}$ & $2.439^{\dagger}$ & & & \\
Observations & $(0.090)$ & $(0.111)$ & $(0.118)$ & & & \\
$\mathrm{R}^{2}$ & 7904 & 5250 & 4607 & & & \\
\hline
\end{tabular}

Note: Years of education, type of danwei, cadre status, and age are all measured for the head of the household. Standard errors in parentheses. Source: 1988, 1995, 2002 China Household Income Project (CHIP).

${ }^{*} p<0.05, \dagger p<0.01$ (two-tailed tests).

Since the reform, family size, as an indicator of need, has continued to affect families' housing space.

The preceding findings, however, might be confounded by other variables not yet considered. Previous studies have revealed large regional variation in income determinants, owing to large cross-city differences in such factors as unequal economic growth, natural resources, industrial bases, local policies, and ties to the central government (Hauser and Xie 2005; Xie and Hannum 1996). To further validate our results and address the problem of regional heterogeneity, we refine the analyses in Tables 2 and 3 by including a city fixed effect. We present the results from the fixed effect models in Tables 4 and 5 .
The income analysis in Table 4 shows that adding city effects does not substantially modify our conclusions from the OLS models in Table 2. The adjusted estimates show that a market determinant, namely education, became a more significant factor in determining a worker's income, whereas redistributive determinants, including danwei and cadre status, continued to serve as important predictors of income over time. Overall, marketization did not lessen either the importance of danwei in income determination or the income premiums of former communist elites. While the magnitudes of the coefficients differ slightly between Tables 2 and 4, statistical tests suggest that the only significant difference is the income difference between danwei. After 
Table 4: Changing Determinants of Income with Regional Fixed Effects

\begin{tabular}{|c|c|c|c|c|c|c|}
\hline Individual income & 1988 & 1995 & 2002 & $\begin{array}{c}1995 \\
\text { vs. } 1988\end{array}$ & $\begin{array}{c}2002 \\
\text { vs. } 1995\end{array}$ & $\begin{array}{c}2002 \\
\text { vs.1988 }\end{array}$ \\
\hline $\begin{array}{l}\text { Market Determinants } \\
\text { Years of schooling }\end{array}$ & $\begin{array}{r}0.014^{\dagger} \\
(0.001)\end{array}$ & $\begin{array}{r}0.028^{\dagger} \\
(0.002)\end{array}$ & $\begin{array}{r}0.050^{\dagger} \\
(0.003)\end{array}$ & $\begin{array}{r}0.014^{\dagger} \\
(0.003)\end{array}$ & $\begin{array}{r}0.022^{\dagger} \\
(0.003)\end{array}$ & $\begin{array}{r}0.036^{\dagger} \\
(0.003)\end{array}$ \\
\hline \multicolumn{7}{|c|}{$\begin{array}{l}\text { Redistributive Determinants } \\
\text { Type of danwei (SOE omitted) }\end{array}$} \\
\hline Government & $\begin{array}{r}-0.095^{\dagger} \\
(0.012)\end{array}$ & $\begin{array}{r}0.109^{\dagger} \\
(0.013)\end{array}$ & $\begin{array}{r}0.140^{\dagger} \\
(0.018)\end{array}$ & $\begin{array}{r}0.204^{\dagger} \\
(0.019)\end{array}$ & $\begin{array}{l}0.031 \\
(0.020)\end{array}$ & $\begin{array}{r}0.235^{\dagger} \\
(0.021)\end{array}$ \\
\hline Private enterprise & $\begin{array}{r}-0.135^{*} \\
(0.055)\end{array}$ & $\begin{array}{r}-0.075 \\
(0.060)\end{array}$ & $\begin{array}{r}-0.101^{\dagger} \\
(0.019)\end{array}$ & $\begin{array}{l}0.060 \\
(0.088)\end{array}$ & $\begin{array}{c}-0.026 \\
(0.061)\end{array}$ & $\begin{array}{c}0.035 \\
(0.067)\end{array}$ \\
\hline Cadre & $\begin{array}{r}0.090^{\dagger} \\
(0.012)\end{array}$ & $\begin{array}{r}0.080^{\dagger} \\
(0.016)\end{array}$ & $\begin{array}{r}0.122^{\dagger} \\
(0.022)\end{array}$ & $\begin{array}{c}-0.010 \\
(0.022)\end{array}$ & $\begin{array}{c}0.042 \\
(0.024)\end{array}$ & $\begin{array}{c}0.032 \\
(0.023)\end{array}$ \\
\hline \multicolumn{7}{|c|}{ Demographic Determinants } \\
\hline Age & $\begin{array}{r}0.013^{\dagger} \\
(0.000)\end{array}$ & $\begin{array}{r}0.010^{\dagger} \\
(0.001)\end{array}$ & $\begin{array}{r}0.004^{\dagger} \\
(0.001)\end{array}$ & $\begin{array}{r}-0.003^{\dagger} \\
(0.001)\end{array}$ & $\begin{array}{r}-0.006^{\dagger} \\
(0.001)\end{array}$ & $\begin{array}{r}-0.009^{\dagger} \\
(0.001)\end{array}$ \\
\hline Family size & $\begin{array}{r}0.024^{\dagger} \\
(0.004)\end{array}$ & $\begin{array}{c}0.005 \\
(0.008)\end{array}$ & $\begin{array}{l}-0.018 \\
(0.011)\end{array}$ & $\begin{array}{r}-0.019^{*} \\
(0.009)\end{array}$ & $\begin{array}{c}-0.023 \\
(0.012)\end{array}$ & $\begin{array}{r}-0.042^{\dagger} \\
(0.010)\end{array}$ \\
\hline Intercept & $\begin{array}{c}6.560^{\dagger} \\
(0.030)\end{array}$ & $\begin{array}{r}8.063^{\dagger} \\
(0.053)\end{array}$ & $\begin{array}{c}8.879^{\dagger} \\
(0.081)\end{array}$ & & & \\
\hline Observations & 7,872 & 5,143 & ,661 & & & \\
\hline $\mathrm{R}^{2}$ & 0.311 & 0.372 & 0.297 & & & \\
\hline
\end{tabular}

Note: All models include city fixed effects. Years of education, type of danwei, cadre status, and age are all measured for the head of the household. Standard errors in parentheses. Source: 1988, 1995, 2002 China Household Income Project (CHIP). ${ }^{*} p<0.05, \dagger p<0.01$ (two-tailed tests).

regional heterogeneity is controlled, we find that workers in private enterprises always experienced a income disadvantage in the period studiedby 13 percent in 1988, 7.5 percent in 1995, and 10.1 percent in 2002 - as compared to workers in state-owned enterprises.

As the last step of the data analysis, we now replicate our earlier analysis of the trends in housing determinants with city fixed effects, shown in Table 5. Consistent with our early findings in Table 3, the fixed effects results suggest a similar decline of redistributive determinants and rise of market determinants of housing space during the housing reform. One noteworthy discrepancy in results between Tables 3 and 5 is that after the city effect is controlled, the changes in the estimated effects of market determinants and re- distributive determinants are more pronounced substantively and more significant statistically. The statistical tests for the changes are presented in the last three columns.

Specifically, findings in Table 5 show that household income was not a significant determinant of family housing space during the initial stages of the reform in 1988 but that its role grew over time. As indicated by the estimated coefficients, each percent increase in household income would result in a 0.122 percent increase in housing space in 1995 and a 0.169 percent increase in 2002. Each additional year of education would lead to a 0.9 percent increase in housing space in 1995 , but that effect would more than double to a 1.9 percent increase in 2002 . In contrast, the housing benefits of cadres compared to ordinary 
Table 5: Changing Determinants of Housing Space with Regional Fixed Effects

\begin{tabular}{lcccccc}
\hline & & & & 1995 & 2002 & 2002 \\
Housing space (logged) & 1988 & 1995 & 2002 & vs. 1988 & vs. 1995 & vs.1988 \\
\hline Market Determinants & & & & & & \\
Household income (log yuan) & 0.015 & $0.122^{\dagger}$ & $0.169^{\dagger}$ & $0.106^{\dagger}$ & $0.048^{\dagger}$ & $0.154^{\dagger}$ \\
& $(0.012)$ & $(0.013)$ & $(0.012)$ & $(0.018)$ & $(0.018)$ & $(0.017)$ \\
Years of schooling & $0.011^{\dagger}$ & $0.009^{\dagger}$ & $0.019^{\dagger}$ & -0.002 & $0.010^{\dagger}$ & $0.008^{\dagger}$ \\
& $(0.002)$ & $(0.002)$ & $(0.002)$ & $(0.003)$ & $(0.003)$ & $(0.003)$ \\
Redistributive Determinants & & & & & & \\
Type of danwei (SOE omitted) & & & & & & \\
$\quad$ Government & $0.114^{\dagger}$ & $0.060^{\dagger}$ & $0.051^{\dagger}$ & $-0.054^{\dagger}$ & -0.009 & $-0.063^{\dagger}$ \\
Private enterprise & $(0.015)$ & $(0.013)$ & $(0.015)$ & $(0.020)$ & $(0.020)$ & $(0.021)$ \\
Cadre & -0.024 & -0.002 & 0.012 & 0.022 & 0.014 & 0.036 \\
& $(0.041)$ & $(0.047)$ & $(0.015)$ & $(0.062)$ & $(0.050)$ & $(0.042)$ \\
Demographic Determinants & $0.150^{\dagger}$ & $0.105^{\dagger}$ & $0.046^{*}$ & $-0.045^{*}$ & $-0.060^{*}$ & $-0.104^{\dagger}$ \\
Age & $(0.015)$ & $(0.016)$ & $(0.018)$ & $(0.022)$ & $(0.024)$ & $(0.023)$ \\
Family size & & & & & & \\
& $0.012^{\dagger}$ & $0.011^{\dagger}$ & $0.006^{\dagger}$ & -0.001 & $-0.006^{\dagger}$ & $-0.006^{\dagger}$ \\
Intercept & $(0.001)$ & $(0.001)$ & $(0.001)$ & $(0.001)$ & $(0.001)$ & $(0.001)$ \\
& $0.065^{\dagger}$ & $0.059^{\dagger}$ & $0.052^{\dagger}$ & -0.006 & -0.007 & -0.013 \\
Observations & $(0.005)$ & $(0.008)$ & $(0.009)$ & $(0.010)$ & $(0.013)$ & $(0.011)$ \\
$\mathrm{R}^{2}$ & $2.332^{\dagger}$ & $1.452^{\dagger}$ & $1.138^{\dagger}$ & & & \\
\hline
\end{tabular}

Note: All models include city fixed effects. Years of education, type of danwei, cadre status, and age are all measured for the head of the household. Standard errors in parentheses. Source: 1988, 1995, 2002 China Household Income Project (CHIP).

${ }^{*} p<0.05, \dagger p<0.01$ (two-tailed tests).

workers declined from 15 percent to only 4.6 percent from 1988 to 2002, and the advantages of government workers compared to those in stateowned enterprises declined from 11.4 percent to only 5 percent. Admittedly, the advantages of redistributive danwei and elites still existed after the reform, but the gaps by danwei and between cadres and ordinary workers have considerably diminished over time.

To summarize, findings from the fixed effect models confirm the conclusion drawn from the ols models: the economic reform, especially during the period in which the housing reform was implemented, has led to a rise in the role of market determinants for both income and housing space and a reduction in the role of redistributive determinants for housing space, but not for income.

\section{Discussion and Conclusion}

In this paper, we argue that housing space is a better outcome variable than income by which to evaluate Nee's market transition theory because it is a more consistent measure of socioeconomic success both before and after the reform. We examine the temporal changes in determinants of housing space using three waves of a national household survey in 1988, 1995, and 2002, and 
compare them with the changes in income determinants. Our results are consistent overall with the predictions of Nee's market transition theory, as market factors gradually replaced redistributive factors in determining housing space.

Do our findings support market transition theory? Yes, but only partially. Our findings support market transition theory to the extent that housing distribution in urban China has indeed made the transition from being mostly redistributionbased to being largely market-based. This conclusion suggests that the marketization goal of the housing reform that began in 1998 was largely achieved over by 2002. However, after 2003, housing prices increased rapidly in most major Chinese cities, making new purchases unaffordable for most Chinese urban residents (Yang and Chen 2014, p.8, p.67). It is possible that during this post-2003 housing price upsurge some families were able to use their political resources to acquire more and better housing units through means such as discounted prices, easier loans, inside information, and even investment capital from selling apartments previously acquired from their work units. However, we only analyzed data up to 2002 because CHIP 2007 data unfortunately did not contain comparable enough variables to be included in this study. An important next step is to conduct similar empirical analyses using more recent data.

At best, the results on the 1988-2002 trends in housing inequality presented in this paper lend support to a weak form of market transition theory. We acknowledge that the conclusion drawn from our study using housing space as the outcome variable cannot be extrapolated to other measures of socioeconomic success, such as educational attainment, earnings and income, occupation, and political power. Because the Chinese state has set different policies for these different domains of life, it is prudent not to make the extrapolation. In other words, it may be necessary that market transition theory be evaluated separately for different socioeconomic outcomes. When findings diverge from studies using different measures, as we show in this paper, they may well demonstrate the complex reality of contemporary Chinese society and the need to treat each domain of Chinese life in its own right.

\section{References}

Adelman, Irma and David Sunding. 1987. "Economic Policy and Income Distribution in China." Journal of Comparative Economics 11(3):444-61. http://dx.doi.org/10.1016/ 0147-5967 (87) 90066-7

Bian, Yanjie. 2002. "Chinese Social Stratification and Social Mobility." Annual Review of Sociology 28:91-116. http://dx.doi.org/10 1146/annurev.soc.28.110601.140823

Bian, Yanjie and John R. Logan. 1996. "Market Transition and the Persistence of Power: The Changing Stratification System in Urban China." American Sociological Review 61(5):739-58. http://dx.doi.org/10.2307/ 2096451

Bian, Yanjie, John R. Logan, Hanlong Lu, Yunkang Pan, and Ying Guan. 1997. "Work Unit and the Commodification of Urban Housing." Chinese Social Sciences (English version) 4:28-35.

Cao, Yang and Victor Nee. 2000. "Comment: Controversies and Evidence in the Market Transition Debate." American Journal of Sociology 105(4):1175-89. http://dx.doi.org/ $10.1086 / 210402$

Chao, Kang. 1966. "Industrialization and Urban Housing in Communist China." The Journal of Asian Studies 25(3):381-96. http://dx doi.org/10.2307/2051997

Chen, Xiangming and Xiaoyuan Gao. 1993. "Urban Economic Reform and Public Housing Investment in China." Urban Affairs Quarterly 29(1):117-45. http://dx.doi.org/10 1177/004208169302900105

Chiswick, Barry. 1971. "Earnings Inequality and Economic Development." Quarterly Journal of Economics 85:21-39. http://dx.doi.org/ $10.2307 / 1881838$

Gerber, Theodore P. and Michael Hout. 1998. "More Shock than Therapy: Market Transition, Employment, and Income in Russia, 1991-1995." American Journal of Sociology 104:1-50. http://dx.doi.org/10.1086/ 210001

Gustafsson, Björn, Shi Li, and Zhong Wei. 2006. "The Distribution of Wealth in Urban China and in China as a Whole 
in 1995." Review of Income and Wealth 52(2):73-188. http://dx.doi.org/10.1111/ j.1475-4991.2006.00183.x

Hauser, Seth M. and Yu Xie. 2005. "Temporal and Regional Variation in Earnings Inequality: Urban China in Transition between 1988 and 1995." Social Science Research 34:44-79. http://dx.doi.org/10.1016/j ssresearch.2003.12.002

Howe, Christopher. 1968. "The Supply and Administration of Urban Housing in Mainland China: The Case of Shanghai." The China Quarterly 33:73-97. http://dx.doi.org/10 1017/S0305741000003775

Huang, Youqin and William A. V. Clark. 2002. "Housing Tenure Choice in Transitional Urban China: A Multilevel Analysis." Urban Studies 39(1):7-32. http://dx.doi.org/10 1080/00420980220099041

Lee, Yok-Shiu F. 1988. "The Urban Housing Problem in China." The China Quarterly 115: 387-407. http://dx.doi.org/10 1017/S0305741000027491

Li, Shi and Renwei Zhao. 2007. "Changes in the Distribution of Wealth in China, 19952002." United Nations University-World Institute for Development Economics Research (UNU-WIDER) Working paper.

Logan John R. and Yanjie Bian. 1993. "Access to Community Resources in a Chinese City." Social Forces 72(2):555-576. http://dx.doi org/10.1093/sf/72.2.555

Logan, John R., Yanjie Bian and Fuqin Bian. 1999. "Housing Inequality in Urban China in the 1990s: Market and Nonmarket Mechanisms." International Journal of Urban and Regional Research 23:7-25. http://dx.doi org/10.1111/1468-2427.00176

Logan, John R., Yiping Fang, and Zhanxin Zhang. 2009. "Access to Housing in Urban China." International Journal of Urban and Regional Research 33:914-935. http://dx.doi.org/ 10.1111/j.1468-2427.2009.00848.x

Logan, John R., Yiping Fang, and Zhanxin Zhang. 2010. "The Winners in China's Urban Housing Reform." Housing Studies 25:101-117. http://dx.doi.org/10.1080/ 02673030903240660
Meng, Xin. 2007. "Wealth Accumulation and Distribution in Urban China." Economic Development and Cultural Change 55:761-91. http://dx.doi.org/10.1086/516761

National Bureau of Statistics. 1996. China Statistics Yearbook (Chinese). Beijing: China Statistical Publishing House.

National Bureau of Statistics. 2003. China Statistics Yearbook (Chinese). Beijing: China Statistical Publishing House.

Nee, Victor. 1989. "A Theory of Market Transition: From Redistribution to Markets in State Socialism." American Sociological Review 54:663-81. http://dx.doi.org/10 2307/2117747

Nee, Victor. 1991. "Social Inequalities in Reforming State Socialism: Between Redistribution and Markets in China." American Sociological Review 56:267-82. http://dx.doi.org/ 10.2307/2096103

Nee, Victor. 1996. "The Emergence of a Market Society: Changing Mechanisms of Stratification in China." American Journal of Sociology 101:908-49. http://dx.doi.org/10 $1086 / 230784$

Nee, Victor and Yang Cao. 2005. "Market Transition and the Firm: Institutional Change and Income Inequality in Urban China." Management and Organization Review 1:23-56. http://dx.doi.org/10.1111/ j.1740-8784.2004.00003.x

Nee, Victor and Rebecca Matthews. 1996. "Market Transition and Societal Transformation in Reforming State Socialism." Annual Review of Sociology 22:401-35. http://dx.doi.org/ 10.1146/annurev.soc.22.1.401

Pan, Guangjun. 2000. "The Process of Chinese Housing Reform." Chinese Reform 11:15-19 (in Chinese).

Pan, Zhenfeng. 2003. "Housing Equality Differentials in Urban China 1988-1995: Evidence from Two National Surveys." International Journal of Social Economics 30:1070-83. http://dx.doi.org/10.1108/ 03068290310492869

Parish, William L. 1984. "Destratification in China." Pp. 84-120 in Class and Social Stratification in Post-Revolution China, edited by 
J. Watson. New York: Cambridge University Press.

Parish, William L. and Ethan Michelson. 1996. "Politics and Markets: Dual Transformations." American Journal of Sociology 101:1042-59. http://dx.doi.org/10.1086/230788

Sato, Hiroshi. 2006. "Housing Inequality and Housing Poverty in Urban China in the Late 1990s." China Economic Review 17(1):37-50. http://dx.doi.org/10.1016/ j.chieco.2004.09.005

State Council. 1998. "A Notification from the State Council on Further Deepening the Reform of Urban Housing System and Accelerating Housing Construction. Document No.23 [Guowuyuan guanyu jingyibu shenhua chengzhen zhufang zhidu gaige jiakuai zhufang jianshe de tongzhi]."

Szelényi, Ivan. 1978. "Social Inequalities in State Socialist Redistributive Economies." International Journal of Comparative Sociology 19:63-87. http://dx.doi.org/10.1177/ 002071527801900105

Szelényi, Ivan. 1983. Urban Inequalities under State Socialism. New York: Oxford University Press.

Szelényi, Ivan and Eric Kostello. 1996. "The Market Transition Debate: Toward a Synthesis?" American Journal of Sociology 101(4):10821096. http://dx.doi.org/10.1086/230791

Walder, Andrew G. 1986. Communist NeoTraditionalism: Work and Authority in Chinese Industry. Berkeley and Los Angeles: University of California Press.

Walder, Andrew G. 1990. "Economic Reform and Income Distribution in Tianjin, 1976-1986." Pp. 135-56 in Chinese Society on the Eve of Tiananmen, edited by D. Davis and E.F. Vogel. Cambridge, MA: Harvard University Press.

Walder, Andrew G. 1992. "Property Rights and Strati?cation in Socialist Redistributive Economies." American Sociological Review 57:524-39. http://dx.doi.org/10.2307/ 2096099

Walder, Andrew G. 1995. "Career Mobility and the Communist Political Order." American Sociological Review 60:309-28. http: //dx.doi.org/10.2307/2096416
Walder, Andrew G. 1996. "Markets and Inequality in Transitional Economies: Toward Testable Theories." American Journal of Sociology 101:1060-73. http://dx.doi.org/10 $1086 / 230789$

Walder, Andrew G. 2002. "Markets and Income Inequality in Rural China: Political Advantage in an Expanding Economy." American Sociological Review 67: 231-253. http: //dx.doi.org/10.2307/3088894

Walder, Andrew G. and Xiaobin He. 2014. "Public Housing into Private Assets: Wealth Creation in Urban China." Social Science Research 46: 85-99. http://dx.doi.org/10 1016/j.ssresearch.2014.02.008

Walder, Andrew G. and Giang Hoang Nguyen. 2008. "Ownership, Organization, and Income Inequality: Market Transition in Rural Vietnam," American Sociological Review 73: 251-269. http://dx.doi.org/10.1177/ 000312240807300204

Walder, Andrew G. and Litao Zhao. 2006. "Political Office and Household Wealth: Rural China in the Deng Era." China Quarterly 186: 357-376. http://dx.doi.org/10 1017/S0305741006000191

Wang, Feng. 2003. "Housing Improvement and Distribution in Urban China: Initial Evidence from China's 2000 Census." The China Review 3(2):121-43.

Wang, Feng. 2008. Boundaries and Categories: Rising Inequality in Post-Socialist Urban China. Stanford University Press.

Wang, Yan. 1995. "Permanent Income and Wealth Accumulation: A Cross-Sectional Study of Chinese Urban and Rural Households." Economic Development and Cultural Change 43(3): 523-550. http://dx.doi.org/ $10.1086 / 452167$

Whyte, Martin K. and William L. Parish. 1984. Urban Life in Contemporary China. Chicago: University of Chicago Press.

Wu, Fulong. 1996. "Changes in the Structure of Public Housing Provision in Urban China." Urban Studies 33(9):1601-27. http://dx.doi org/10.1080/0042098966529

Wu, Jing, Joseph Gyourko, and Yongheng Deng. 2012. "Evaluating Conditions in 
Major Chinese Housing Markets." Regional Science and Urban Economics 3:531-43. http://dx.doi.org/10.1016/j regsciurbeco.2011.03.003

Wu, Xiaogang. 2002. "Work Units and Income Inequality: the Effect of Market Transition in Urban China." Social Forces 80 (3):1069-99. http://dx.doi.org/10.1353/ sof. 2002.0013

Wu, Xiaogang and Yu Xie. 2003. "Does the Market Pay Off? Earnings Returns to Education in Urban China." American Sociological Review 68(3): 425-42. http://dx.doi.org/10 $2307 / 1519731$

Xia, Qingjie, Lina Song, Shi Li, Simon Appleton. 2013. "The Effect of the State Sector on Wage Inequality in Urban China: 1988-2007." IZA Discussion Paper Series No.7142 http://papers.ssrn.com/ sol3/papers.cfm?abstract_id $\$=\$ 2207283$ http://papers.ssrn.com/sol3/papers. cfm?abstractid2207283

Xie, Yu and Emily Hannum. 1996. "Regional Variation in Earnings' Inequality in Reformera Urban China." American Journal of Sociology 102:950-92. http://dx.doi.org/10 $1086 / 230785$

Xie, Yu and Xiang Zhou. 2014. "Income Inequality in Today's China." Proceedings of the National Academy of Sciences (PNAS) 111: 6928-6933. http://dx.doi.org/10.1073/ pnas.1403158111

Yang, Zan, and Jie Chen. 2014. Housing Affordability and Housing Policy in Urban China. Berlin: Springer. http://dx.doi.org/10 1007/978-3-642-54044-8

Yang, Xiaomin, and Yihu Zhou. 1999. China's Danwei System. Beijing: Chinese Economy Press (in Chinese).

Yemtsov, Ruslan. 2007. "Housing Privatization and Household Wealth in Transition." United Nations University, World Institute for Development Economics Research, Research Paper No. 2007/02.

Zang, Xiaowei. 1999. "Urban Housing Reforms in China." Pp. 49-79 in China in the Reform Era, edited by X. Zang. Commack, NY: Nova Science Publishers.
Zhao, Wei, and Xueguang Zhou. 2002. "Institutional Transformation and Returns to Education in Urban China: An Empirical Assessment." Research in Social Stratification and Mobility 19: 339-75. http://dx.doi.org/10 1016/S0276-5624(02)80046-4

Zhou, Min and John R. Logan. 1996. "Market Transition and the Commodification of Housing in Urban China." International Journal of Urban and Regional Research 20:400-21. http://dx.doi.org/10.1111/j 1468-2427.1996.tb00325.x

Zhou, Xueguang. 2000. "Economic Transformation and Income Inequality in Urban China: Evidence from Panel Data." American Journal of Sociology 105 (4):1135-74. http://dx.doi.org/10.1086/210401

Acknowledgements: We are grateful to Yanjie Bian, Robert Mare, Raymond Sin-Kwok Wong, Xiaogang $\mathrm{Wu}$, Hua Ye, and Zhuoni Zhang for their comments and suggestions. An earlier version of this paper was presented at the 2009 annual meeting of the ISA Research Committee on Social Stratification (RC28), Beijing (May 14-16).

Xi Song: Department of Sociology, University of California, Los Angeles.

E-mail: songxi@ucla.edu.

Yu Xie: Department of Sociology, University of Michigan.

E-mail: yuxie@umich.edu. 